\title{
Physico-Chemical, Microbiological and Sensory Changes in Sun-dried Trichogaster fasciata During Storage
}

\author{
Md. Golam Rasul ${ }^{1, a}$, Bhaskar Chandra Majumdar ${ }^{1, b}$, Faria Afrin ${ }^{1, c}$, Mueena Jahan, \\ Yuan Chunhong,e, A.K.M. Azad Shah ${ }^{1, f, *}$ \\ ${ }^{1}$ Department of Fisheries Technology, Bangabandhu Sheikh Mujibur Rahman Agricultural University, Gazipur - 1706, Bangladesh \\ ${ }^{2}$ Department of Microbiology \& Public Health, Bangabandhu Sheikh Mujibur Rahman Agricultural University, Gazipur - 1706, Bangladesh \\ ${ }^{3}$ Department of Food Production and Environmental Management, Faculty of Agriculture, Iwate University, 3-18-8 Ueda, Morioka, Japan \\ *Corresponding author

\section{A R T I C L E I N F O} \\ Research Article \\ Received : 07/04/2019 \\ Accepted : 16/08/2019 \\ Keywords: \\ Trichogaster fasciata \\ Chemical composition \\ Lipid oxidation \\ Microbial load

\section{A B S T R A C T} \\ Sun dried (T. fasciata) was stored with airtight polyethylene bags at room temperature to investigate \\ the changes in physical, chemical, microbiological and sensory characteristics for 90 days. Sensory \\ and physical (water reconstitution, $\mathrm{pH}$ ) characteristics of dried $T$. fasciata showed that the product \\ was acceptable up to 60 days of storage. Moisture content of $T$. fasciata was significantly increased \\ from $15.06 \%$ to $17.80 \%$ during the storage period. No significant difference was observed in protein, \\ lipid and ash content on dry matter basis during storage. However, amount of lipids of the dried fish \\ was slightly decreased with the increasing of storage time. The $\mathrm{pH}$ value of dried $T$. fasciata was \\ decreased significantly from 6.51 to 5.94 during the storage period. The peroxide value was \\ increased from 13.84 to $27.87 \mathrm{meq} / \mathrm{Kg}$ of lipid. Similarly, acid value and conjugated diene of the \\ lipids were increased significantly, and this result suggested that lipid oxidation occurred over this \\ period of time. Microbial load was also increased from 1.13 to $8.37 \mathrm{log}$ CFU/g with the increasing \\ of storage time. Results of this study showed that the product was oxidized marginally during the \\ storage period and suitable for human consumption up to 60 days.
}

Storage time

\section{Introduction}

Fish is one of the most important sources of animal protein and other essential nutrients for the maintenance of a healthy body (Arannilewa et al., 2005; Öz, 2016; Öz et al., 2017) of which a significant part comes from dried fishes. Dried fish is an exceptionally favourite food item among Bangladeshi people. Moreover, the product is easily storable, transportable and marketable, and has a high consumer acceptance (Majumdar et al., 2017). The dried fish products are also highly preferred by the consumers due to their traditionally desirable taste, flavour and high level of $\omega-3$ unsaturated fatty acids that have numerous health benefits for human ( $\mathrm{Li}$ et al., 2003). Nowadays, people are more aware about their health and nutritional quality of food when purchasing it for their consumption (Hossain et al., 2008; Öz, 2018). Many studies have already been conducted on the chemical composition of various dried marine fishes (Tawfik, 2009; Sutharshiny and Sivashanthini, 2011). However, chemical changes of dried freshwater fish during storage have not been studied so far.

Production of dried fish in Bangladesh is usually carried out by traditional sun drying in the open air. However, traditionally produced dried fish are not safe for human due to random use of different kinds of pesticides and extreme level of insect infestation (Bhuiyan et al., 2008). Netting and neem (Azadirachta indica) leaves are generally used to minimize this problem. Another major problem of dried fish product is microbial and fungal growth, which can be reduced by maintaining proper drying and packaging of the product. On the other hand, the storage time is shortened due to lipid oxidation of dried fish product as well as the product quality is reduced. 
Previous result suggests that the degree of lipid oxidation is very high in the dried fish products available in Bangladesh (Majumdar et al., 2017). It has been reported that consumption of lipid oxidized products may cause adverse effects (aging, heart disease, brain dysfunction and cancer) on human body (Kinsella, 1987).

About 240 freshwater fish species are found in Bangladesh and most of them are small indigenous fish. Kholisa, Trichogaster fasciata is an important and widely accepted dried fish product in Bangladesh for its characteristic taste, flavour and low price. Moreover, dried T. fasciata contains comparatively higher amount of lipid among the other species, which is susceptible to oxidation. However, changes in quality especially oxidation of lipids during storage of this product has not been studied so far. Therefore, this study was conducted to evaluate the changes in physico-chemical, microbiological and sensory characteristics of sun dried $T$. fasciata during storage.

\section{Materials and Methods}

\section{Collection of Fish Samples}

The experiment was conducted in the Department of Fisheries Technology of Bangabandhu Sheikh Mujibur Rahman Agricultural University (BSMRAU), Gazipur. Freshwater Kholisa ( $T$. fasciata) (length $8.76 \pm 0.74 \mathrm{~cm}$, and weight $13.36 \pm 2.81 \mathrm{~g}$ ) were caught early in the morning and purchased from a fish market in Gazipur and were transported to the laboratory in an insulated ice box. Fish were preserved in ice before processing.

\section{Sun Drying Method of Fish}

In traditional sun drying method, collected fishes were gutted, washed and spread on the bamboo mats without any pre-treatment such as icing, salting etc. The fish was then dried under the sun for 5-6 days until the moisture content reduced to approximately $15-20 \%$. The dried fish was packed by airtight polythene bag and stored at room temperature $\left(24^{\circ} \mathrm{C}\right.$ to $\left.29^{\circ} \mathrm{C}\right)$. During the storage period, quality of the dried fish was investigated after every 30 days interval by determining the physical, chemical, microbiological and sensory aspects up to acceptable limit for human consumption.

\section{Determination of Sensory Properties}

Color, odor, texture, broken pieces and insect infestation of the traditionally produced sun-dried fishes were examined by sensory analysis according to the method described by Rasul et al. (2018). Sensory evaluation was performed in the separated sensory booths. The panel was composed of seven trained assessors (ages between 22 and 35 years) from the Department of Fisheries Technology of BSMRAU.

\section{Evaluation of Water Reconstitution Behaviour}

Water reconstitution behavior was investigated following the method described by Hasan et al. (2016) with slight modification. Briefly, about 8-10 g of sample was weighed and immerged into water at room temperature (24 to $29^{\circ} \mathrm{C}$ ), $40^{\circ} \mathrm{C}$ and $60^{\circ} \mathrm{C}$ for 60 minutes. The soaked dried fish was taken out from water at every 15 minutes interval and reweighed. Per cent water reconstitution was calculated using the following formula;
Water reconstitution $(\%)=\frac{\mathrm{Wr}-\mathrm{Wi}}{\mathrm{Wi}} \times 100$

Where,

$\mathrm{W}_{\mathrm{i}}=$ Initial weight of dried fish

$\mathrm{W}_{\mathrm{r}}=$ Final weight of rehydrated dried fish

\section{Determination of $\mathrm{pH}$}

The dried fish $(10 \mathrm{~g})$ was homogenized with $100 \mathrm{ml}$ of distilled water and the $\mathrm{pH}$ was directly determined using a pH meter (MeterLab PHM 310, China).

\section{Analysis of Proximate Composition}

The proximate composition such as moisture, crude protein, crude lipid and ash content were analyzed according to standard procedure given in AOAC (2006) methods.

\section{Extraction of Lipid}

Total lipid was extracted from dried fish by the Bligh and Dyer (1959) method. The extracted lipid was stored in chloroform at $-20^{\circ} \mathrm{C}$ until further analysis.

\section{Determination of Peroxide Value}

Peroxide value was measured according to AOAC (2006) methods. About $0.5 \mathrm{~g}$ of total lipids was added to glacial acetic acid and chloroform solution $(3: 2, \mathrm{v} / \mathrm{v})$ in a conical flask. Saturated potassium iodide $(0.5 \mathrm{~mL})$ was added to the mixture and kept in the dark for 10 minutes. Then distilled water $(30 \mathrm{~mL})$ and freshly prepared $1 \%$ starch $(0.5 \mathrm{~mL})$ were added to it. The solution was shaken and titrated with $0.01 \mathrm{~N}$ sodium thiosulfate. The result was expressed as meq/Kg of lipid.

\section{Determination of Acid Value}

To measure acid value, $0.5 \mathrm{~g}$ of total lipid was mixed with ethanol and diethyl ether solution $(1: 1, \mathrm{v} / \mathrm{v})$ and phenolphthalein was added to it. The mixture was then titrated with $0.01 \mathrm{~N}$ potassium hydroxide. The result was expressed as $\mathrm{mg} \mathrm{KOH} / \mathrm{g}$ lipid (AOAC, 2006).

\section{Determination of Conjugated Diene}

To determine conjugated diene (CD), $0.1 \mathrm{~g}$ of total lipid was mixed with isooctane $(5.0 \mathrm{~mL})$. A spectrophotometer (UV-1601, Shimadzu, Japan) was used to measure the CD at $234 \mathrm{~nm}$ (Frankel et al., 1996).

\section{Estimation of Microbial Load}

Microbial load of the dried fish was estimated using aerobic plate count method. Physiological saline solution $(0.85 \% \mathrm{NaCl})$ and plate count agar (Hi media, India) were prepared according to the methods given in Cowan and Steel's manual (Barraw and Feltheam, 1993).

\section{Statistical Analysis}

All the analyses were carried out by one-way ANOVA. All data are expressed as mean \pm standard deviation (SD). Duncan's multiple range test (DMRT) was done to compare the means at 5\% level of significance. All analyses were performed using statistical software, Statgraphics (StatPoint Inc., Virginia, USA) version 7.0. 


\section{Results and Discussion}

Changes in Physical and Sensory Characteristics of $T$.
fasciata
Changes in physical and sensory characteristics during storage of dried T. fasciata are presented in Table 1. Characteristic color and odor were observed in the dried fish up to 30 days of storage period. Texture of the dried fish was firm and flexible during this period. On the other hand, color was turned into slightly yellowish in the 60 days then it was turned into slightly brownish in the 90 days of storage period. Moreover, sensory scores also revealed that the dried fish products were in excellent quality up to 60 days of storage period (Table 2). In the dried fish, non-enzymatic browning reaction might be attributed to the changes in color, which progressed continuously during the storage period (Koizumi et al., 1992). Firmness of texture and odor of dried fish was lost in the 60 days of storage period. However, slightly rancid and dried fish odor was decreased in the 90 days of storage period. Infestation of insects and disrupted muscles of dried fish were not found in the sample over the storage time.

\section{Water reconstitution Behaviour of Dried Fish}

The water holding capacity of dried fish products were shown to increase with the increase of reconstitution temperature and time and the rehydration ability decreases with the increase of storage time (Figure 1). It was observed that 0 day dried $T$. fasciata were shown to hold $61.72 \%$ water after 60 minutes at room temperature, whereas 30 days, 60 days and 90 days dried products were shown to have $48.87 \%, 42.94 \%$ and $40.94 \%$, respectively.

Similar trend was also observed when dried fish were soaked at $40{ }^{\circ} \mathrm{C}$ and $60^{\circ} \mathrm{C}$ for $60 \mathrm{~min}$. Sikorski et al. (1995), found that water uptake of dried fish is completed within 3 to 15 minutes. Dried fish with poor texture (tough, rubbery and compact structure of muscle) had poor water reconstitution ability (Connell, 1957; Lahiry et al., 1961).
Moreover, rehydration ability was proportionate to physical properties of dried fish (Reza et al., 2005, Rahman et al., 2017). The muscle structure of a species, reconstitution time and temperature were also influenced the rehydration ability of food products (Brennan et al., 1990; Nurullah, 2005; Akintunde, 2008).

Changes in $p H$ Value of Dried Fish

The $\mathrm{pH}$ value of dried $T$. fasciata was significantly $(\mathrm{P}<0.05)$ decreased from 6.51 to 5.94 during the storage period (Figure 2). The decreasing trend of $\mathrm{pH}$ in the dried fish is almost similar to that reported by Shah et al. (2009). They found that the $\mathrm{pH}$ value was decreased from 6.79 to 6.42 during drying of herring fillets and they also suggested that the decrease in $\mathrm{pH}$ might be due to the formation of free fatty acids produced by lipolysis as well as glycogen was decomposed to lactic acid during drying. Similar results were also observed by Nakagawa et al. (2007), whom found that $\mathrm{pH}$ was decreased from 6.50 to 6.35 during industrial soft drying of herring fillets.

\section{Changes in Chemical Composition of T. fasciata}

The moisture content of $T$. fasciata was significantly increased from $15.06 \%$ to $17.80 \%$ during the storage period (Table 3). The highest moisture content was found in the $90^{\text {th }}$ day which might be due to moisture was absorbed during the storage period. The highest (63.57\%) crude protein content was found in the dried fish stored for 0 day, while the lowest $(62.97 \%)$ was observed at 90 days. However, no significant difference was found in the protein content during the storage period. Bhuiyan (1992) reported that the crude protein of dried Harpodon nehereus and Johnius dussumieri varied from $55.8 \%$ to $75.9 \%$. Haque et al. (2013) found that the protein content of Silver pomfret and Bombay duck ranged from 41.16 to $54.32 \%$, and 50.66 to $54.58 \%$, respectively in traditional sun dried samples. They also reported that the solar dried fish contains comparatively higher amount of protein than the traditional sun dried samples.

Table 1 Changes in physical characteristics during storage of dried T. fasciata.

\begin{tabular}{|c|c|c|c|c|c|c|}
\hline ST & Colour & Odour & Texture & II & $\mathrm{BP}$ & OQ \\
\hline 0 & $\begin{array}{l}\text { Slightly blackish and silvery } \\
\text { (Characteristics colour) }\end{array}$ & Characteristic & Firm and flexible & Nil & Nil & Excellent \\
\hline 30 & $\begin{array}{l}\text { Slightly blackish and } \\
\text { yellowish }\end{array}$ & Characteristic & Firm and flexible & Nil & Nil & Excellent \\
\hline 60 & Slightly yellowish & $\begin{array}{l}\text { Slightly decrease of dried fish } \\
\text { odour }\end{array}$ & $\begin{array}{l}\text { Some loss of } \\
\text { firmness }\end{array}$ & Nil & Nil & Good \\
\hline 90 & Slightly brownish & $\begin{array}{l}\text { Slightly rancid and decrease of } \\
\text { dried fish odour }\end{array}$ & $\begin{array}{l}\text { Tough and some } \\
\text { loss of elasticity }\end{array}$ & Nil & Nil & Average \\
\hline
\end{tabular}

ST: Storage time (days), II: Insect infestation, BP: Broken pieces, OQ: Overall quality

Table 2 Sensory score of $T$. fasciata.

\begin{tabular}{l|ccccc}
\hline ST & Colour & Odour & Texture & Insect Infestation & Overall Quality \\
\hline 0 & $1.38 \pm 0.48$ & $1.60 \pm 0.18$ & $1.63 \pm 0.29$ & $0.00 \pm 0.00$ & Excellent \\
30 & $3.21 \pm 0.21$ & $1.95 \pm 0.84$ & $1.93 \pm 0.38$ & $1.00 \pm 0.00$ & Excellent \\
60 & $4.30 \pm 0.17$ & $3.85 \pm 0.31$ & $3.63 \pm 0.32$ & $1.00 \pm 0.00$ & Good \\
90 & $5.84 \pm 0.12$ & $6.60 \pm 0.26$ & $4.76 \pm 0.13$ & $1.60 \pm 0.41$ & Average \\
\hline
\end{tabular}

ST: Storage time (days) 


$$
\text { (A) }
$$

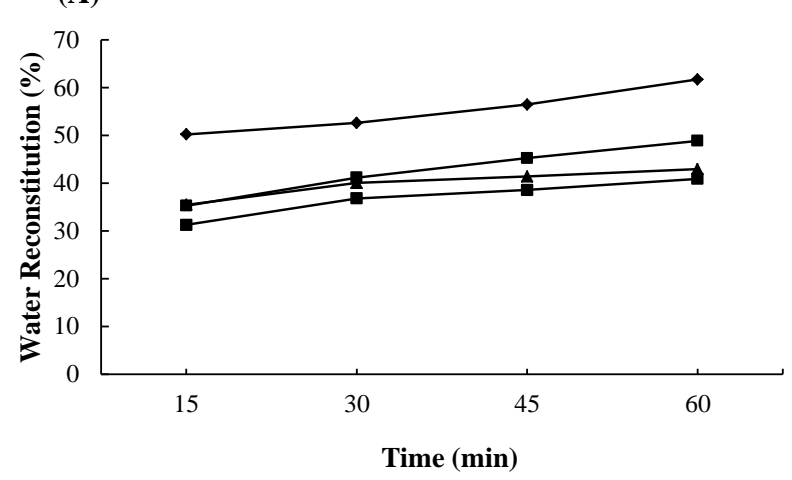

(B)

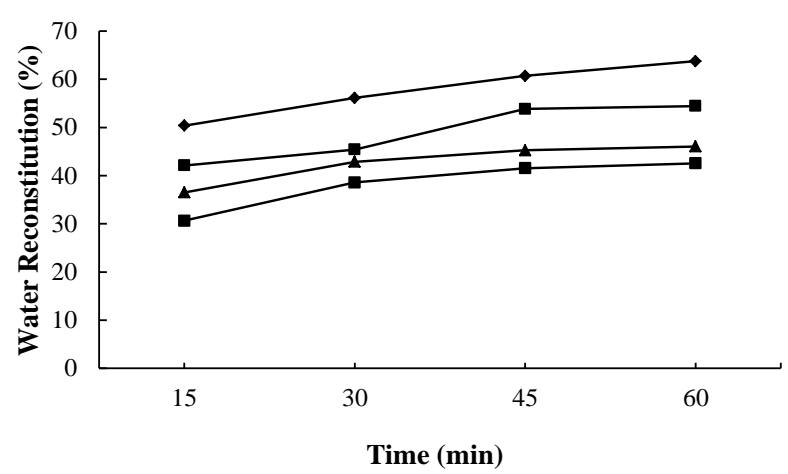

(C)

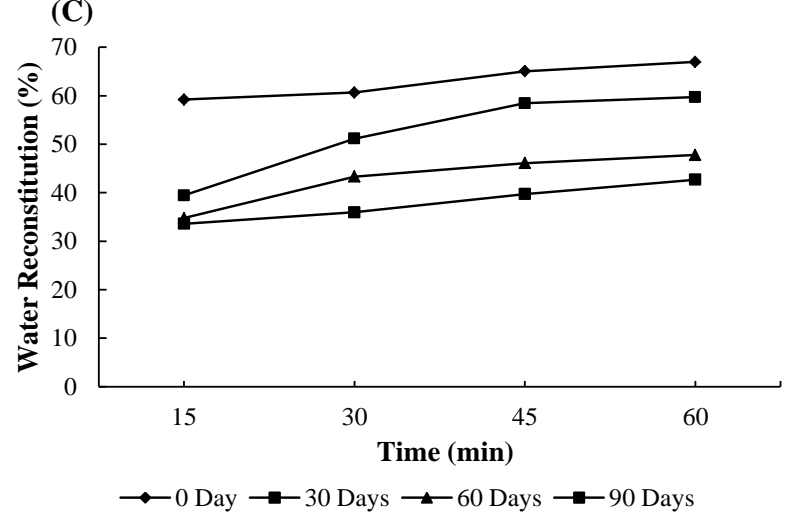

Figure 1 Water reconstitution of sun dried $T$. fasciata at (A) room temperature, (B) $40^{\circ} \mathrm{C}$, and (C) $60^{\circ} \mathrm{C}$ during storage

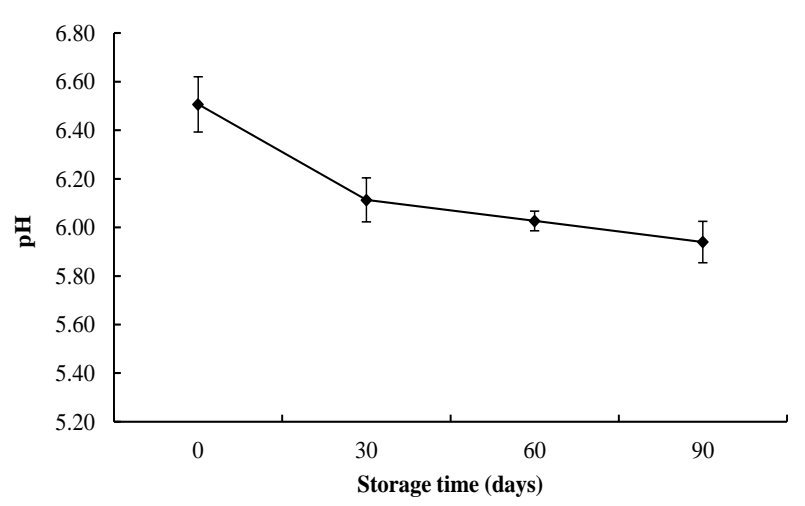

Figure 2 Changes in $\mathrm{pH}$ values during storage of dried $T$. fasciata
Crude lipid content of $T$. fasciata was decreased gradually from $12.97 \%$ to $12.07 \%$ by the 60 day of storage period and then it was slightly increased to $12.13 \%$ by the 90 day of storage period on dry matter basis. The lipid content was decreased from $13.80 \%$ to $11.50 \%$ in the pickled herring during 1 year of storage (Aro et al., 2005). Ash content of $T$. fasciata was varied between $22.73 \%$ and $23.17 \%$ during the storage period. Overall, there was an inverse relationship between moisture content and other chemical composition (crude protein, crude lipid, and ash content on fresh matter basis) of dried fish stored for 90 days.

\section{Oxidation of Lipid During Storage of Dried Fish}

Changes in lipid oxidation (peroxide value, acid value and CD) of dried T. fasciata during storage are shown in Table 4. Oxidation of lipid in fish muscle usually develops off-flavor and off-odor that ultimately affects the storage time (Ramanathan and Das, 1992). Peroxide value of $T$. fasciata was significantly increased from 13.84 to 27.87 $\mathrm{meq} / \mathrm{Kg}$ of lipid during the storage period. The highest peroxide value was found at 90 days of storage period and the value was higher than the acceptable limit ( $P V \leq 20$ $\mathrm{meq} / \mathrm{Kg}$ fish lipid) for human consumption (Connell, 1995). Shah et al. (2009) reported that peroxide value of herring (Clupea pallasii) lipids (5.52-11.86 meq/Kg) significantly increased during drying. Moreover, lipids were degraded during the storage period, which had effect on fish flavor due to the presence of unsaturated fatty acids (Kawai and Sakaguchi, 1996; Alasalvar et al., 2005). Pacheco-Aguilar et al. (2000) also observed an increase in peroxide value of Monterey sardine muscle during storage at $0^{\circ} \mathrm{C}$ for 15 days. Moreover, lipid hydroperoxides are readily decomposed into a wide range of carbonyl compounds, hydrocarbons, ketones, and other materials that contribute to off flavor of food (Frankel, 1991).

In addition to peroxide value, acid value was determined to measure the degree of lipid hydrolysis in dried fish. Generally, fish muscle lipids are hydrolyzed by the activity of lipases and phospholipases, which releases free fatty acids (Pacheco-Aguilar et al., 2000). In this study, acid value of $T$. fasciata lipid was increased slightly from 12.05 to $13.75 \mathrm{mg} \mathrm{KOH} / \mathrm{g}$ of lipid within 30 days of storage and then increased gradually up to 90 days (22.25 $\mathrm{mg} \mathrm{KOH} / \mathrm{g}$ of lipid) of storage period (Table 4$)$. Since the amount of FFAs in fish muscle increases during storage, it is known that there is a close relation between the amount of FFAs and loss of fish freshness (Barassi et al., 1987). This result suggests that the formation of free fatty acid is one of the important factors to increase acid value in the dried fish product. In addition, these free fatty acids were further oxidized and produced secondary oxidation products, which generates characteristic taste and off-odor of fish and fishery products (Toyomizu et al., 1981).

A progressive formation of oxidized products can also be determined by measuring conjugated diene (CD) of lipid. Generally, after per-oxidation of lipids, polyunsaturated fatty acids are changed to conjugated double bonds $(\mathrm{C}=\mathrm{C}-\mathrm{C}=\mathrm{C})$ from the non-conjugated double bonds $(\mathrm{C}=\mathrm{C}-\mathrm{C}-\mathrm{C}=\mathrm{C})$ (Gunstone and Norris, 1983). As a result, the optical density of $234 \mathrm{~nm}$ is increased (Zuta et al., 2007), which is an indicator of auto-oxidation in lipids (Weber et al., 2008). In this study, the CD value of dried $T$. fasciata lipid was increased with the increasing of storage time (Table 4). Significantly the highest 
CD value was observed at 90 days of storage period. Changes in CD value of $T$. fasciata lipid might be due to the formation and decomposition rates of conjugated double bonds in lipids (Chaijan et al., 2006). A gradual increase of CD value was also observed in dorsal muscle of Atlantic pomfret stored in chilled condition for a prolonged period (Perez-Alonso et al., 2003).

\section{Microbial Changes in T. fasciata During Storage}

Changes in microbial load of dried T. fasciata during storage are depicted in Table 5. Total plate count of $T$. fasciata were $1.13 \log \mathrm{CFU} / \mathrm{g}, 5.44 \log \mathrm{CFU} / \mathrm{g}, 6.02 \mathrm{log}$ CFU/g and $8.37 \log \mathrm{CFU} / \mathrm{g}$ at 0, 30, 60 and 90 days, respectively. It was observed that the microbial load of $T$. fasciata increased with the increasing of storage period. It has been reported that acceptable limit of total plate count for fresh fish is $7 \mathrm{log}$ CFU/g (Ojagh et al., 2010). Mansur et al. (2013) reported that the total bacterial count of some sun-dried fishes was ranged between $1.84 \times 10^{4}$ and $5.3 \times$ $10^{6} \mathrm{CFU} / \mathrm{g}$. The aerobic plate count of some marine dried fish products was ranged between 3.27 and $4.49 \mathrm{log} \mathrm{CFU} / \mathrm{g}$ (Reza et al., 2009).

\section{Conclusion}

The physical and sensory characteristics of $T$. fasciata revealed that the product was excellent quality up to 30 days but acceptable up to 90 days of storage period. Moreover, the dried fish causes some chemical changes and at the same time lipid oxidation was progressed during storage. Microbial load also showed that the product was acceptable for human consumption up to 90 days of storage. Results of this study demonstrated that the dried fish was oxidized gradually over the storage time and safe for human consumption up to two or less than three months of storage.

Table 3 Changes in chemical composition (\% fresh matter) of dried T. fasciata during storage ${ }^{1}$.

\begin{tabular}{c|crrc}
\hline ST & \multicolumn{1}{|c}{ Moisture } & \multicolumn{1}{c}{ Protein } & Lipid & Ash \\
\hline 0 & $15.06 \pm 0.13^{\mathrm{a}}$ & $53.98 \pm 0.57^{\mathrm{a} 1}\left(63.55 \pm 0.67^{\mathrm{d}}\right)$ & $11.02 \pm 0.09^{\mathrm{a}}\left(12.97 \pm 0.10^{\mathrm{d}}\right)$ & $19.68 \pm 0.38^{\mathrm{a}}\left(23.17 \pm 0.44^{\mathrm{d}}\right)$ \\
30 & $16.32 \pm 0.08^{\mathrm{b}}$ & $53.19 \pm 1.27^{\mathrm{ab}}\left(63.57 \pm 1.52^{\mathrm{d}}\right)$ & $10.69 \pm 0.98^{\mathrm{a}}\left(12.77 \pm 1.17^{\mathrm{d}}\right)$ & $19.02 \pm 0.34^{\mathrm{a}}\left(22.73 \pm 0.41^{\mathrm{d}}\right)$ \\
60 & $17.09 \pm 0.15^{\mathrm{bc}}$ & $52.31 \pm 0.53^{\mathrm{b}}\left(63.09 \pm 0.64^{\mathrm{d}}\right)$ & $10.01 \pm 0.38^{\mathrm{a}}\left(12.07 \pm 0.45^{\mathrm{d}}\right)$ & $18.95 \pm 0.34^{\mathrm{a}}\left(22.86 \pm 0.40^{\mathrm{d}}\right)$ \\
90 & $17.80 \pm 0.92^{\mathrm{c}}$ & $51.76 \pm 0.92^{\mathrm{b}}\left(62.97 \pm 1.11^{\mathrm{d}}\right)$ & $9.97 \pm 0.91^{\mathrm{a}}\left(12.13 \pm 1.10^{\mathrm{d}}\right)$ & $18.93 \pm 0.83^{\mathrm{a}}\left(23.03 \pm 1.01^{\mathrm{d}}\right)$ \\
\hline
\end{tabular}

${ }^{1}$ Means with different characters (a, b, c denote fresh matter; $d$ denotes dry matter) within a column indicates significant differences $(\mathrm{P}<0.05)$, ST: Storage time (days)

Table 4 Changes in peroxide value, acid value and CD of dried T. fasciata during the storage period ${ }^{1}$.

\begin{tabular}{c|ccc}
\hline ST & Peroxide Value $(\mathrm{meq} / \mathrm{Kg}$ of lipid) & Acid value $(\mathrm{mg} \mathrm{KOH} / \mathrm{g}$ of lipid) & CD $(\mathrm{OD} 234 \mathrm{~nm})$ \\
\hline 0 & $13.84 \pm 0.71^{\mathrm{a}}$ & $12.05 \pm 0.40^{\mathrm{a}}$ & $3.369 \pm 0.022^{\mathrm{a}}$ \\
30 & $16.23 \pm 0.64^{\mathrm{b}}$ & $13.75 \pm 0.33^{\mathrm{b}}$ & $3.394 \pm 0.065^{\mathrm{a}}$ \\
60 & $19.17 \pm 0.76^{\mathrm{c}}$ & $16.24 \pm 0.64^{\mathrm{c}}$ & $3.437 \pm 0.031^{\mathrm{a}}$ \\
90 & $27.87 \pm 0.97^{\mathrm{d}}$ & $22.25 \pm 0.75^{\mathrm{d}}$ & $3.542 \pm 0.040^{\mathrm{b}}$ \\
\hline
\end{tabular}

${ }^{1}$ Means with different characters within a column indicates significant differences $(\mathrm{P}<0.05)$, ST: Storage time (days)

Table 5 Changes in microbial load (CFU/g) of dried T. fasciata during storage.

\begin{tabular}{c|c}
\hline Storage time (days) & Microbial load (log CFU/g) \\
\hline 0 & 1.13 \\
30 & 5.44 \\
60 & 6.02 \\
90 & 8.37 \\
\hline
\end{tabular}

\section{Conflicts of interest}

The authors declare that they have no conflict of interest.

\section{Acknowledgements}

The authors wish to thank the Research Management Committee (RMC) of BSMRAU, Gazipur and University Grant Commission (UGC), Bangladesh for financial support.

\section{References}

Akintunde TY. 2008. Effect of soaking water temperature and time on some rehydration characteristics and nutrient loss in dried bell pepper. Agric Eng Int: CIGR Journal, 10: 8-13.

Alasalvar C, Taylor AKD, Shahidi F. 2005. Comparison of volatiles of cultured and wild sea bream (Sparus aurata) during storage in ice by dynamic headspace analysis/gas chromatography-mass spectrometry. J Agric Food Chem, 53: 2616-2622. doi: 10.1021/jf0483826
AOAC, Association of Official Analytical Chemists. 2006. Official methods of analysis of AOAC international ( $18^{\text {th }} \mathrm{ed}$.). Virginia, USA: Association of Official and Analytical Chemists International.

Arannilewa ST, Salawu SO, Sorungbe AA, Ola-Salawu BB. 2005. Effect of frozen period on the chemical, microbiological and sensory quality of frozen tilapia fish (Sarotherodun galiaenus). Afr J Biotechnol, 4: 852-855.

Aro TL, Larmo PS, Backman CH, Kallio HP, Tahvonen RL. 2005. Fatty acids and fat-soluble vitamins in salted herring (Clupea harengus) products. J Agric Food Chem, 53: 14821488. doi: 10.1021/jf0401221

Barassi CA, Pècora RP, Roldán H, Trucco RE. 1987. Total nonvolatile free fatty acids as a freshness index for hake (Merluccius hubbsi) stored in ice. J Sci Food Agril, 38: 373-376.

Barraw GL, Feltham RKA. 1993. Cown and steet's manual for the identification of medical bacteria, $2^{\text {th }}$ Eds. Cambridge University Press, U.K.

Bhuiyan MNH, Bhuiyan HR, Rahim M, Ahmed K, Haque KMF, Hassan MT, Bhuiyan MNI 2008. Screening of organchlorine insecticides (DDT and Heptachlor) in dry fish available in Bangladesh. Bangladesh J Pharmacol, 3(2): 114-120. doi: http://dx.doi.org/10.3329/bjp.v3i2.997 
Bhuiyan MR. 1992. Proximate biochemical analysis and spoilage patter of six marine fishes of the Bay of Bengal. MSc Thesis, Institute of Marine Science and Fisheries, University of Chittagong, Chittagong, Bangladesh.

Bligh EG, Dyer WJ. 1959. A rapid method of total lipid extraction and purification. Can J Physiol Pharmacol, 37: 911-917. doi: https://doi.org/10.1139/y59-099

Brennan JG, Butters JR, Cowell ND, Lilly AEV. 1990. Food engineering operations. (3rd Eds.), Applied Science, London. pp. 123-130.

Chaijan M, Benjakul S, Visessanguan W, Faustman C. 2006. Changes of lipids in sardine (Sardinella gibbosa) muscle during iced storage. Food Chem, 99: 83-91. doi: https://doi.org/10.1016/j.foodchem.2005.07.022

Connell JJ. 1957. Some aspects of the texture of dehydrated fish. J Sci Food Agric, 8(9): 326-353. doi: 10.1002 /jsfa.2740080907

Connell JJ. 1995. Control of fish quality ( $4^{\text {th }}$ Eds.). Oxford: Fishing News Books.

Frankel EN, Huang SW, Prior E, Aeschbach R. 1996. Evaluation of antioxidant activity of rosemary extracts, carnosol and carnosic acid in bulk vegetable oils and fish oil and their emulsions. J Agric Food Chem, 72(2): 201-208. doi: 10.1002/(SICI)1097-0010(199610)72:2<201: AID-JSFA632> 3.0.CO;2-Q

Frankel EN. 1991. Review: Recent advances in lipid oxidation. J Sci Food Agril, 54: 495-511.

Gunstone FD, Norris FA. 1983. Oxidation. In: Gunstone F.D., Norris, F.A. (editors). Lipid in foods: chemistry, biochemistry and technology. New York: Pergamon Press. pp. 58-65.

Haque E, Kamruzzaman M, Islam MS, Sarwar T, Rahman SS, Karim MR. 2013. Assessment and comparison of quality of solar tunnel dried Bombay duck and Silver Pomfret with traditional sun dried samples. Int J Nutr Food Sci, 2(4): 187195. doi: 10.11648/j.ijnfs.20130204.15

Hasan MM, Rasul MG, Ferdausi HJ, Trina BD, Sayeed A, Shah AKMA, Bapary MAJ. 2016. Comparison of organoleptic and chemical characteristics of some traditional and improved dried fish products. Res J Animal Veterinary and Fishery Sci, 4(2): 1-6.

Hossain MM, Heinonen V, Islam, KMZ. 2008. Consumption of foods and foodstuffs processed with hazardous chemicals: A case study of Bangladesh. Int J Consum Stud, 32(6): 588-595. doi: $10.1111 /$ j.1470-6431.2008.00690.x

Kawai T, Sakaguchi M. 1996. Fish flavor. Crit Rev Food Sci Nutr, 36: 257-298. doi: https://doi.org/10.1080 $/ 10408399609527725$

Kinsella JE. 1987. Seafood and fish oils in human diseases. New York: Marcel Dekker Inc.

Koizumi C, Kurobe S, Nonaka J. 1959. On the browning of dried fish products. Bull Jpn Soc Sci Fish, 25: 368-372.

Lahiry NL, Sen D, Visweswariah P. 1961. Effect of varying proportions of salt to fish on the quality of sun drying mackerel. Food Sci, 10(5): 139-143.

Li D, Bode O, Drummond H, Sinclair AJ. 2003. Omega-3 (n-3) fatty acids. In: Gunstone, F.D. (eds.), Lipids for Functional foods and Nutraceuticals, (pp. 225-262). Bridgwater, England: The Oily Press.

Majumdar BC, Afrin F, Rasul MG, Khan M, Shah AKMA. 2017. Comparative study of physical, chemical, microbiological and sensory aspects of some sun dried fishes in Bangladesh. Braz J Biol Sci, 4(8): 323-331. doi: https://dx.doi.org /10.21472/-bjbs.040811

Mansur MA, Rahman S, Khan MNA, Reza MS, Kamrunnahar, Uga S. 2013. Study on the quality and safety aspect of three sun-dried fish. Afr J Agric Res, 8(41): 5149-5155. doi: 10.5897/AJAR12.773

Nakagawa R, Noto H, Yasokawa D, Kamatani T. 2007. Microbiological and chemical changes during the industrial soft-drying process of migaki-nishin herring. Nippon Shokuhin Kagaku Kogaku Kaishi, 54: 26-32.
Nurullah M. 2005. Quality assessment and improvement of traditionally dried small indigenous fish of Bangladesh. $\mathrm{PhD}$ Thesis, Department of Fisheries Technology, Bangladesh Agricultural University, Mymensingh, Bangladesh. pp. 184.

Ojagh SM, Rezaei M, Razavi SH, Hosseini SMH. 2010. Effect of chitosan coatings enriched with cinnamon oil on the quality of refrigerated rainbow trout. Food Chem, 120: 193-198. doi: https://doi.org/10.1016/j.foodchem.2009.10.006

Öz M, Dikel S, Durmuş M, Özoğul Y. 2017. Effects of black cumin oil (Nigella sativa) on sensory, chemical and microbiological properties of rainbow trout during 23 days of storage at $2 \pm 1{ }^{\circ} \mathrm{C}$. J Aquat Food Prod Tech, 26(6): 665-674.

Öz M. 2016. Nutrition and gender effect on body composition of rainbow trout (Oncorhynchus mykiss). J Adv Vetbio Sci Tech, 1(1): 20-25.

Öz M. 2018. Effects of garlic (Allium sativum) supplemented fish diet on sensory, chemical and microbiological properties of rainbow trout during storage at $-18^{\circ} \mathrm{C}$. LWT-Food Sci Tech, 92: $155-160$.

Pacheco-Aguilar R, Lugo-Sánchez ME, Robles-Burgueńo MR. 2000. Postmortem biochemical and functional characteristic of Monterey sardine muscle stored at $0{ }^{\circ} \mathrm{C}$. J Food Sci, 65: 40-47. doi: 10.1111/j.1365-2621.2000.tb15953.x

Perez-Alonso F, Arias C, Aubourg SP. 2003. Lipid deterioration during chilled storage of Atlantic Pomfret (Brama brama). Eur J Lipid Sci Technol, 105: 661-667. doi: 10.1002/ejlt.200300804

Rahman MS, Rasul MG, Hossain MM, Uddin W, Majumdar BC, Sarkar MSI, Bapary MAJ. 2017. Impact of Spice Treatments on the Quality and Shelf Life of Sun Dried Taki (Channa punctatus). J Chem Biol Phys Sci, 7(2): 409-420.

Ramanathan L, Das NP. 1992. Studies on the control of lipid oxidation in ground fish by some polyphenolic natural products. J Agric Food Chem, 40: 17-21. doi: 10.1021/jf00013a004

Rasul MG, Majumdar BC, Afrin F, Shah AKMA. 2018. Biochemical, microbiological and sensory properties of dried Silver carp (Hypophthalmichthys molitrix) influenced by various drying methods. Fishes, 3(3): 1-11. doi:10.3390 /fishes3030025

Reza MS, Bapary MAJ, Azimuddin KM, Nurullah M, Kamal M. 2005. Studies on the traditional drying activities of commercially important marine fishes of Bangladesh. Pak J Biol Sci, 8(9): 1303-1310.

Reza MS, Bapary MAJ, Islam MN, Kamal M. 2009. Optimization of marine fish drying using solar tunnel dryer. J Food Process Preserv, 33: 47-59. doi: 10.1111/j.1745-4549.2008.00236.x

Shah AKMA, Tokunaga C, Kurihara H, Takahashi, K. 2009. Changes in lipids and their contribution to the taste of migakinishin (drying herring fillet) during drying. Food Chem, 115: 1011-1118. doi: https://doi.org/10.1016/j.foodchem. 2009.01.023

Sikorski ZE, Gildberg A, Ruiter A. 1995. Fish Products. In: Fish and Fishery Products, composition, nutritive properties and stability. Ed. By Ruiter, A. Depart, CAB International, The Netherlands.

Sutharshiny S, Sivashanthini K. 2011. Proximate composition of three species of Scomberoides fish from Sri Lankan waters. Asia J Clin Nutr, 3: 103-111.

Takiguchi A. 1992. Lipid oxidation and brown discoloration in niboshi during storage at ambient and low temperatures. Nippon Suisan Gakkaishi, 58: 489-494.

Tawfik MS. 2009. Proximate composition and fatty acids profiles in most common available fish species in Saudi market. Asia J Clin Nutr, 1: 50-57.

Toyomizu M, Hanaoka K, Yamaguchi K. 1981. Effect of release of free fatty acids by enzymatic hydrolysis of phospholipids on lipid oxidation during storage of fish muscle at $-5^{\circ} \mathrm{C}$. Bull Jpn Soc Sci Fish, 47: 605-610. doi: https://doi.org/10.2331/suisan.47.615 
Weber J, Bochi VC, Ribeiro CP, Victorio AM, Emanuelli T. 2008. Effect of different cooking methods on the oxidation, proximate and fatty acid composition of silver catfish (Rhamdia quelen) fillets. Food Chem, 106: 140-146. doi: https://doi.org/10.1016/j.foodchem.2007.05.052
Zafar M, Siddiqui MZH, Hoque MA. 2004. Biochemical composition in Scylla serrata (Forskal) of Chakaria Sundarban area, Bangladesh. Pak J Biol Sci, 7: 2182-2186.

Zuta PC, Simpson BK, Zhao X, Leclerc L. 2007. The effect of $\alpha$ tocopherol on the oxidation of Mackerel oil. Food Chem, 100(2): 800-807. doi: https://doi.org/10.1016/-j.foodchem. 2005.11 .003 